\title{
The evolution of the NHS
}

\author{
Frank Honigsbaum
}

\section{London W2 5BS}

Frank Honigsbaum, PHD, associate research fellow of King's College, London

BrMed J 1990;301:694-9
Women at Westminster Union Workhouse, 1877 (after H Herkamer)
Britain has a record of parliamentary government noted for its conservative tendencies, yet it has produced the most radical and comprehensive public health service in the world. How did this happen? Were health needs greater in Britain than elsewhere? Was the private sector less able to cope? Did the public press more strongly for state aid? Was the nation better able to afford it? None of these questions seem to point in a satisfactory direction; the main forces behind the development of the National Health Service have to be looked for elsewhere.

\section{The dreaded poor law}

State intervention in health care began almost accidentally, as a result of the establishment of the poor law in 1601 . That statute required the "necessary relief of the lame, impotent, old, blind and such other among them being poor and not able to work." Thereafter a rudimentary system of medical relief arose under which those who were too poor to pay were supplied with physic by a parish doctor. This system was never intended to spread beyond the ranks of the poor. Indeed, in 1834 an attempt was made to curb pauperism with the introduction of a workhouse test: those wanting relief had to enter a hated workhouse before they could receive it. Two years earlier a more frightening deterrent had been posed with the passage of the Anatomy Act, making the corpses of the poor liable to dissection. ${ }^{2}$ Though the sick were exempted from the workhouse test and could still be treated at home, the system became stigmatised. No one sought poor law relief if it could possibly be avoided.

The public did not feel the same reluctance to use the municipal health services that arose in the nineteenth century. Throughout the period, local authority efforts were concentrated on environmental reform but, starting with the provision of asylums for the mentally ill and isolation hospitals for those with infectious disease, municipal attention shifted increasingly to personal care. What drove local authorities on were the persistently high maternal and infant mortalities that disturbed the nation. ${ }^{3}$ Something had to be done, and medical officers of health found the public receptive to the free maternal and child welfare services they offered.

This movement led some to think that the time had come to reform the poor law and put all public health services under the care of local authorities. By 1909 the Fabian socialists Sidney and Beatrice Webb had become the leading exponents of this idea. Working closely with Sir Arthur Newsholme and other medical officers they made it the key to their campaign to break up the poor law; even government officials who administered the system had begun to wonder whether the principles of "deterrence" and "less eligibility" should be applied to health care.

\section{Local Government Act}

Had this programme carried it is doubtful whether a universal service would have emerged. The Webbs had been so anxious to placate their critics that they even excluded the higher paid workers from the public sector. They wanted to unify the public health service first and to worry about its extension later. Not until 1929 was their goal realised with the passage of the Local Government Act, which abolished the boards of guardians who administered the poor law and gave local authorities the chance to convert Poor Law institutions into municipal hospitals, thereby making indoor as well as outdoor medical relief more readily available. ${ }^{4}$ To placate the doctors and voluntary hospitals who feared the loss of patients a means test

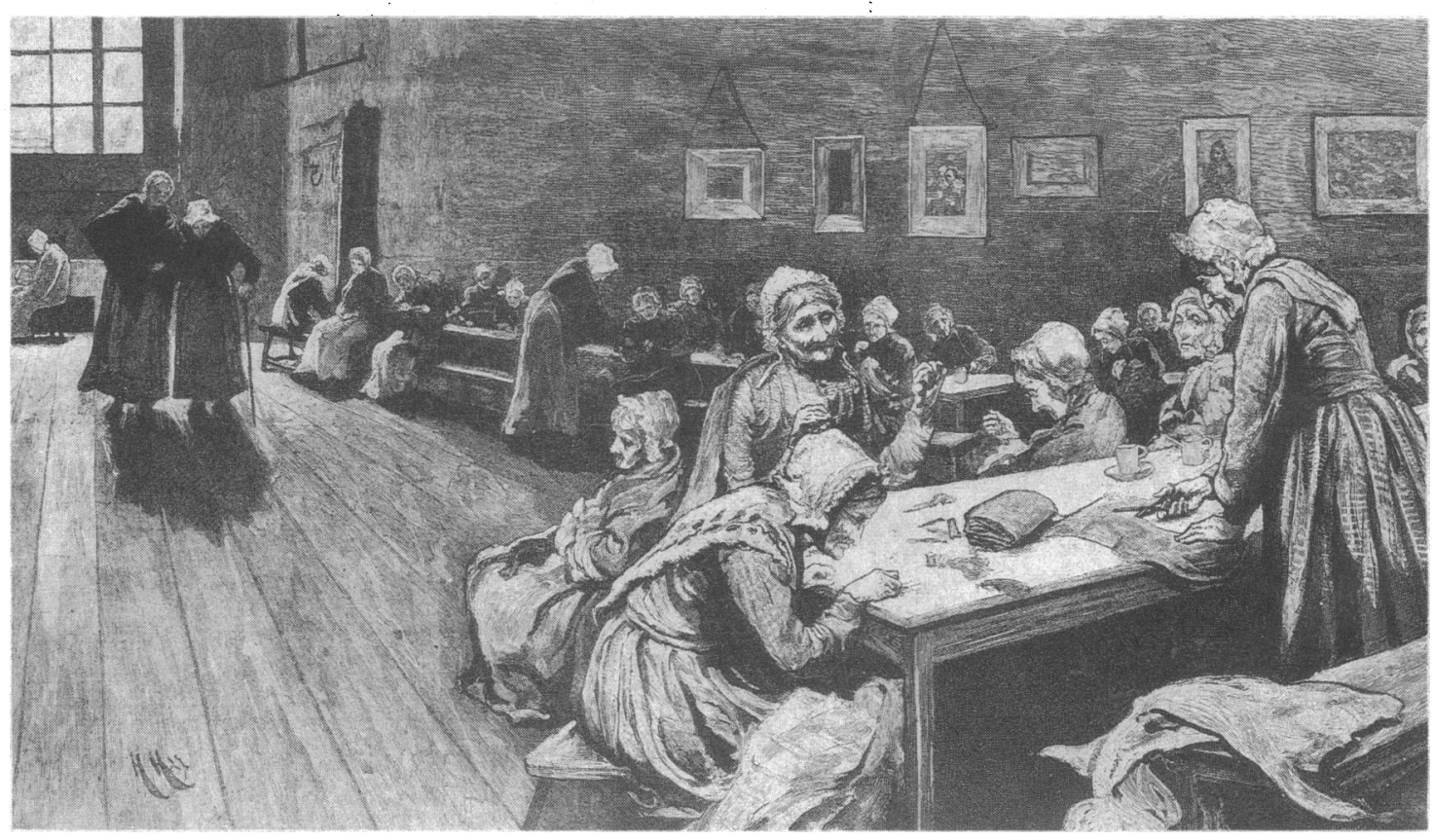




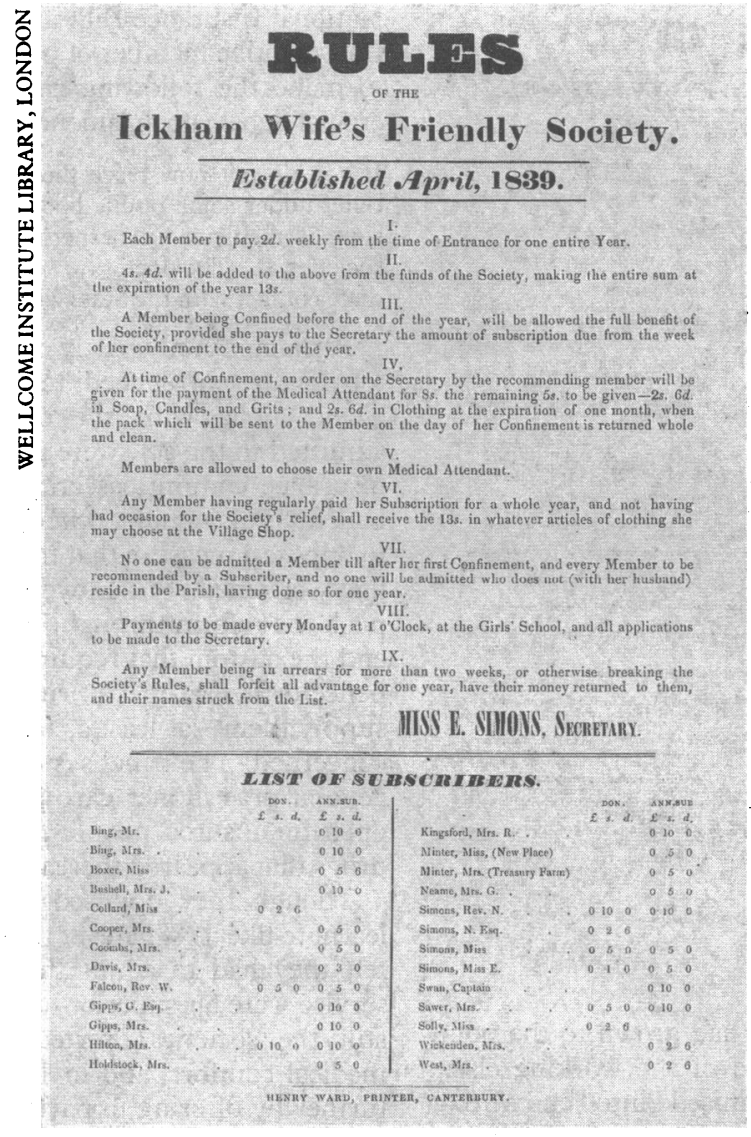

still had to be applied, and all who could afford to pay were expected to do so. Though the procedure was not strictly enforced, it did slow the growth of municipal services. Women, children, the unemployed, and others who had been excluded from the health care provided under National Insurance applauded municipal efforts and looked forward to the development of a comprehensive service, but those who lost income from the process were determined to frustrate them.

The strongest opposition came from the medical profession. Before the 1930s doctors had been more concerned with threats to their position under the panel system - the method by which medical benefit was provided through National Insurance. But as that danger subsided the profession turned its attention to the growth of municipal services, aroused by sharp clashes between general practitioners and medical officers of health in the years between the wars. There was a particularly important clash in Croydon in 1937, where the medical officer of health failed to consult local doctors during the course of an outbreak of typhoid, which resulted in 42 deaths before he was able to diagnose the cause. This gave medical leaders the chance to condemn the absence of consultative machinery throughout the country. Throughout the 1930s the leading figure in the British Medical Association, Sir Henry Brackenbury, had sought to forge an accommodation with public health workers in the hope of finding a suitable place for private practitioners in the framework of municipal care. But by the time discussions on the postwar health service began in 1943 the profession wanted nothing to do with the proposal. General practitioners and consultants alike were determined to keep their distance from medical officers of health.

Ministry of Health officials found it hard to accept this view. From the moment the panel system began in 1913 Sir Robert Morant and the civil servants who administered it had longed for the day when it could be combined with municipal care under the direction of medical officers of health. That, in their view, was the logical way to organise public health services, and politicians from all parties agreed with them. The plan the ministry presented to the profession in 1943 called for all care to be organised under local authority direction, and general practitioners were to be employed in health centres and receive a salary. The system long desired by that doyen of the public health world, Sir Arthur Newsholme, was at last to be realised: health services were to be consolidated under medical officer of health control.

Had the ministry stuck to this conception it is certain that the postwar service would not have taken the form it did. Instead of a comprehensive service open to everyone the department would have had to restrict care to those below an income limit just as the Webbs had done in 1909. The profession would never have accepted the $100 \%$ principle in that form. Indeed, as it turned out, the doctors forced the removal of municipal direction from all but a limited array of community services, and even those were taken away when the National Health Service was reorganised in $1974 .^{5}$ At that point medical officers of health disappeared as well, their place being taken by community physicians or public health officers, whose role was to plan or evaluate services rather than provide them.

\section{Crucial role of club practice}

If neither poor law nor municipal developments were sufficient to produce a universal service where then did the movement towards a national health service come from? The most likely source lies in the nature of club practice, which was started by friendly societies in the nineteenth century and which, by the intolerable conditions it imposed, made a frustrated medical profession that was unable to produce reforms on its own and was receptive to state intervention. Ironically, this made the doctors themselves the driving force behind the development of a wider public service. The system of general practice that exists today still bears the earmarks of the rudimentary arrangements that were clumsily erected in the 1820 s.

Club practice began innocently enough. As the industrial revolution proceeded working men found it desirable to protect themselves against adversity and recourse to the hated poor law; they formed friendly societies like the Manchester Unity of Oddfellows to provide, among other benefits, cash support when ill. But how could the societies be certain that members were really incapacitated? Doctors were needed to ensure the payment of legitimate benefits, adding whatever care they could provide in their surgeries to restore patients to health. Because at that time most doctors did their own dispensing they were expected to provide drugs. For this service the societies generally offered payment in the form of a capitation fee as it was easier to administer. The amount, when club practice began, was about two to three shillings a year, and by 1911, when parliament intervened, it had risen only to four shillings despite the increasing cost of drugs.

Doctors nevertheless saw the work as a useful supplement to private practice that brought within reach the wives and children who were generally excluded from the clubs. In an age when orthodox medicine had little to offer club practice also afforded protection against competition by unqualified practitioners. Parliament formally endorsed the arrangement in 1858 with the passage of the Medical Act, which not only established a register of qualified doctors but also restricted club and public practice to those who were on it.

But the profession could live with club practice only so long as it assumed modest proportions. By the end of 


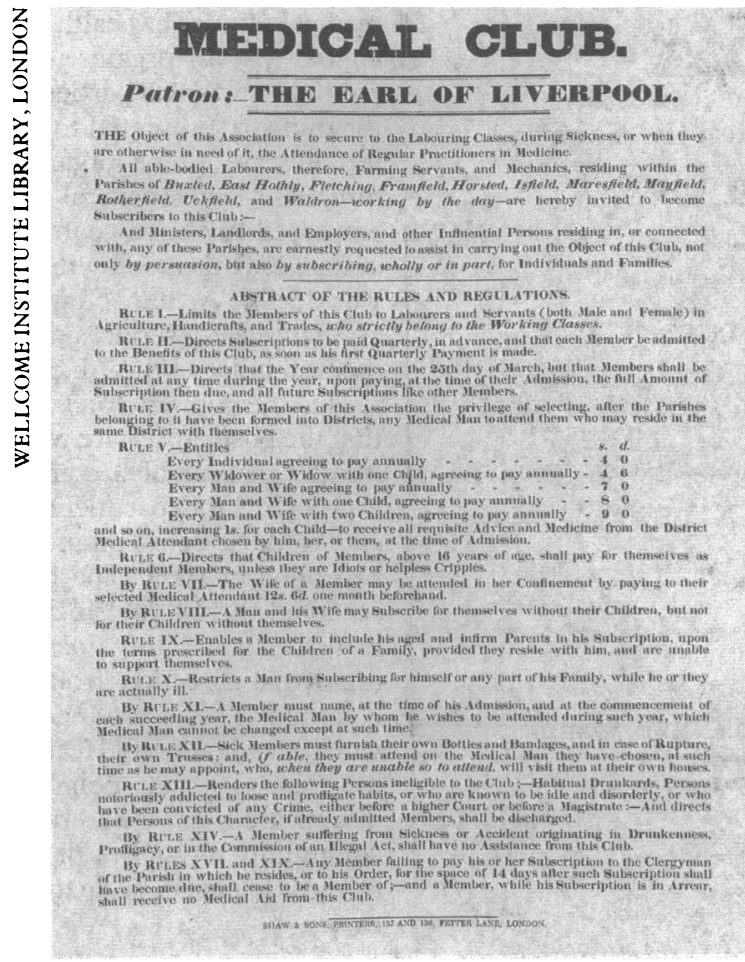

the century friendly societies had grown to the point where they covered one third of the working class. Countless others were organised into clubs that followed the example of the friendly societies so that an ever increasing number of doctors were drawn into the work, with some four or five thousand being so involved that they depended on club income for their subsistence.

Nor was low pay the only problem: the clubs were controlled by laymen, and doctors had no voice in administration. Some medical men suffered severe indignities, including interference in clinical work. At one club in Birmingham only one minute was allowed for consultations, and if the practitioner exceeded that time "a loud knocking at the surgery door brought the consultation to a close." A J Cronin, in his classic novel The Citadel, has left us with a graphic account of the harsh treatment handed out to doctors in clubs run by coal miners in south Wales. ${ }^{6}$

\section{Need for state intervention}

From the middle of the nineteenth century doctors in some places made sporadic attempts to reform club practice, but they failed. The profession was overcrowded, and practitioners from other places were all too ready to take the appointments abandoned by local men. National organisation was needed, and the BMA supplied it in the wake of the "battle of the clubs" that began in 1895. An account of this struggle, written by a special commissioner, appeared in the Lancet over a period of 20 years, while the $B M \mathcal{F}$ published an extensive study of the economic conditions of contract practice in 1905.

Despite the Herculean efforts of medical leaders the profession could not secure appreciable reform. The BMA itself was split by the conflict, with leading consultants resisting the efforts of general practitioner advocates to secure the trade union powers needed for effective action. It soon became apparent to BMA officials like Drs James Smith Whitaker and Alfred Cox (then secretary and deputy secretary respectively) that state aid was needed to free the profession from the control of the friendly societies.

Lloyd George gave the doctors the opportunity to move towards state control in 1911 with his
National Insurance Bill, and Dr Cox used an extreme Conservative member of parliament, Sir Henry Craik, to make the following ringing declaration during a crucial debate on an amendment to the bill:

If you do not now place the administration of the medical relief under some public body ... you will place the profession of medicine in perpetuity under the heel of private societies. .. . The doctors ... desire to be brought into immediate contact with the State whose servants they are.

Parliament only partly complied; the societies were too firmly entrenched to be completely displaced. They, along with the other "approved societies" admitted to the act, were given a $60 \%$ majority on the insurance committees created to administer medical benefit. This, among other provisions, led the doctors to oppose a measure that their more perceptive leaders had welcomed. But Lloyd George was determined to push the reform through. Above all else he wanted to end the custom that required doctors to supply drugs; henceforth, except in rural areas, chemists would supply them-at least as far as the Insurance Act was concerned. The panel system began in 1913 with only general practitioner care provided, but the way was open for insured people to benefit from the wonder drugs that appeared thereafter.

Though they opposed the act, the doctors soon learnt to like it. Whatever lingering dissatisfaction they felt they had to admit that the conditions of panel service were far superior to those in club practice. But still the societies exerted too much influence for medical comfort, and in 1922 they tried to extend it further by offering to pay the excess costs of medical benefit from the surplus funds they had accumulated under the Insurance Act. In the midst of this dispute Dr Cox again made the profession's preference clear:

I would rather see the State provide the money. Our Civil Service is incorruptible. I would rather see the Government standing between the insured persons and the medical profession than the approved societies, some of which want the Government to stand aside.

Even the rival Medical Practitioners' Union - then a thorn in the side of BMA leaders-shared the same view: "The danger is not that we may have more State interference with our work but that we may have less."

\section{The growing municipal threat}

The dispute, which ended with a "glorious victory" for the doctors, ${ }^{9}$ proved to be a turning point in the development of medical benefit. Thereafter society influence waned and the profession turned its attention to the growing threat from the municipal sector. Local authority clinics were spreading fast, and hospital services were expected to follow in the wake of the Local Government Act 1929. As women who did not work and children were excluded from medical care under the Insurance Act medical officers of health concentrated their efforts for them. Practitioners everywhere became alarmed by the way maternity and child welfare clinics were "stealing" their patients.

The profession's way of meeting this threat was to call for more state intervention. It wanted the panel extended to cover "dependants and specialists"- that

\section{0s}

- 1866: Thomas Clifford Allbutt develops the modern clinical thermometer

- 1867: Joseph Lister publishes his description of antiseptic surgery, which he had been practising for two years 
is, the wives and children of insured people and the medical services provided by specialists. In that way independent practitioners could absorb the work done by local authority clinics. In 1929, when the BMA first published the plan, the doctors were willing to accept municipal administration, but nine years later, when it was reissued, they felt it safer to stick with insurance committees. Clashes with medical officers had led them to fear municipal rule more than society interference.

\section{BMA and TUC alliance and the Beveridge report}

BMA leaders ideally wanted to free the profession from both municipal rule and society interference, and the trade unions gave them the opportunity. By the 1930s the unions had become alarmed at the way the insurance industry was influencing social policy. In 1912 the industrial insurance offices had been admitted to the Insurance Act along with friendly societies, trade unions, and other bodies; but whereas the insurance offices managed to enrol half of the insured people the unions secured only $11 \%$, and even that small proportion fell to $8 \%$ by 1938 . From the time the Insurance Act began spokesmen for the insurance industry proved more astute than friendly society leaders, and by the 1930s they were bringing great pressure to bear on social policy. In 1932 an act was passed that, owing to growing unemployment, threatened 200000 insured people with the loss of medical benefit, thereby leaving them, in the words of one friendly society critic, "crucified on the cross of the insurance principle."

Even worse for the unions was the way that casualty insurance companies and employers administered the public workmen's compensation programme Workers with industrial injuries found themselves forced to accept miserly lump sum settlements that left no recourse but the poor law after the money was exhausted. Some doctors - particularly orthopaedists - shared the unions' concern, and in 1935 the BMA issued a report on fracture treatment that severely criticised the insurance industry. ${ }^{10}$

By this time the profession had also become concerned by the industry's influence on maternity policy. The cash maternity benefit paid under the Insurance Act was the most popular the statute had to offer, and industrial insurance agents found it a ready source of finance for the purchase of life policies. In 1929 when that benefit was under threat the insurance offices cleverly managed to avoid a cut with a scheme that called for the expansion of municipal services, justifying their plan with a severe criticism of the way that general practitioners provided antenatal care.

The moment was ripe for an alliance between the doctors and the unions. In 1936 the BMA formed a joint committee with the Trades Union Congress to facilitate cooperation. While the congress endorsed the BMA's maternity policy the BMA condemned the practices of the insurance industry and employers before government committees investigating workmen's compensation and rehabilitation from industrial accidents. The combination was too strong for the government to ignore. While in 1936 England and Wales adopted a maternity act based on municipal provision in 1937 Scotland adopted a different statute, which made room for general practitioners as the BMA wanted. Then, in 1938, the government created a royal commission with a core of union supporters to study the whole question of workmen's compensation.

Though the outbreak of war gave employers an excuse to boycott the commission's proceedings and force its suspension, the movement started by the BMA and Trades Union Congress proved too strong to stop. It was reinforced by the formation of the Emergency Medical Service in 1939 to deal with the expected civilian casualties of bombing raids and which led to the radical reorganisation of hospital services during the second world war. In 1941, after additional pressure from the Trades Union Congress, the government created a committee headed by Sir William Beveridge to consider not just workmen's compensation but the whole field of social policy. Nor did Beveridge disappoint the unions: when his report appeared in 1942 it endorsed nearly all of the congress's policies. Beveridge called not only for the removal of the insurance industry from state administration but also for the abolition of the approved society system.

\section{Impact of the Medical Planning Commission}

Meanwhile, the doctors were not silent. In 1940 they had formed a Medical Planning Commission, which in June 1942 produced an interim report calling for the creation of a comprehensive health service covering $90 \%$ of the population. Though this amounted to little more than an endorsement of the extension proposals published by the BMA in 1929 and 1938, it carried greater weight because the scheme now had the support of the prestigious consultants who led the royal colleges.

The profession's report came five months before Beveridge's appeared, and that made it easy for Beveridge to add an assumption to his plan that called for the creation of a comprehensive health service covering the nation as a whole. As the secretary of the Beveridge Committee later disclosed, the proposal had a strategic purpose-it "provided the main argument against the Approved Society system." Both recommendations were subsequently accepted by the government.

At that point (November 1942) it looked like the doctors would slip easily into a service that was open to everyone; indeed, at its annual representative meeting two months earlier the BMA had approved the concept by a small majority. But throughout the period the profession made it clear that it would not accept municipal control, and the civil servants at the 


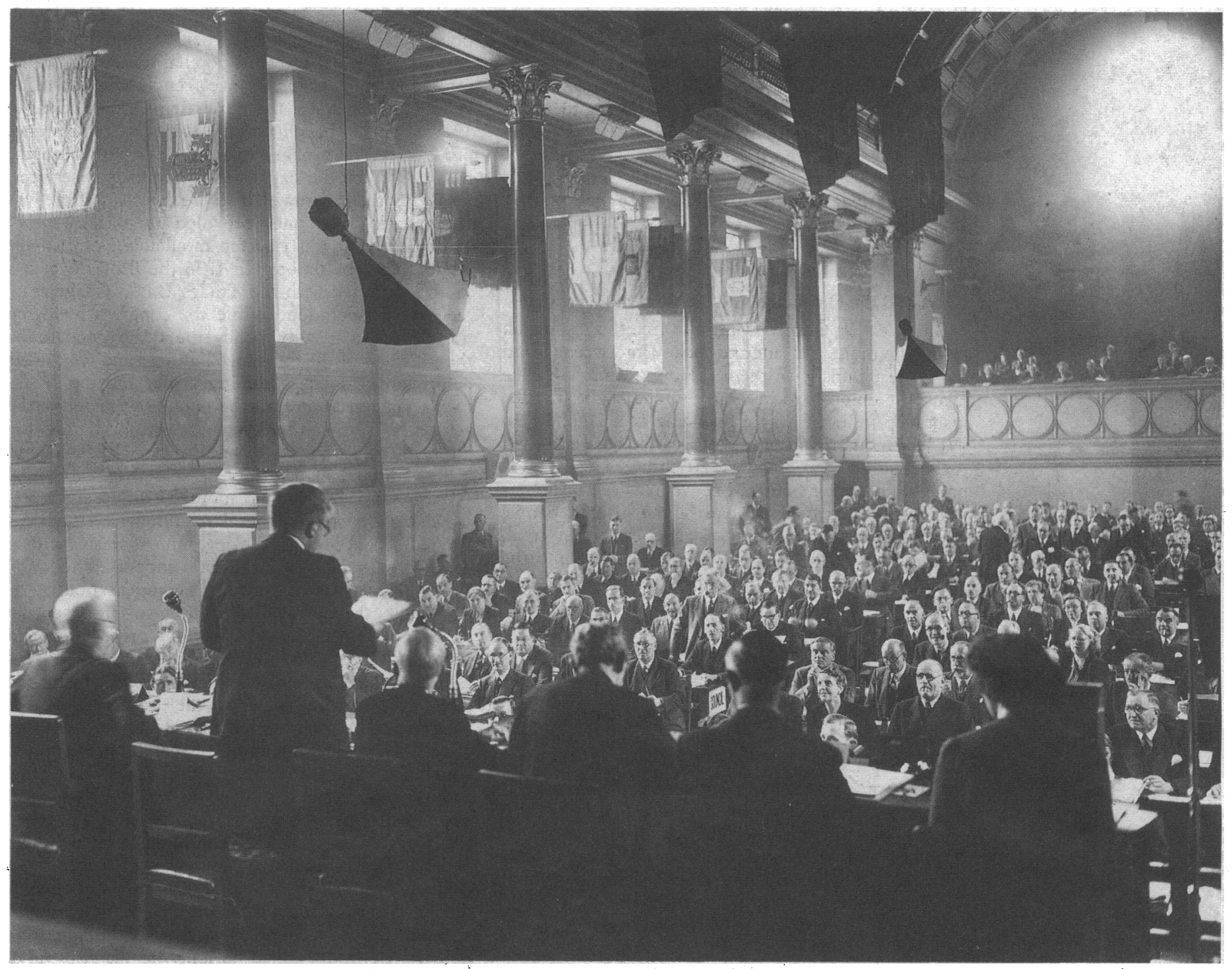

When the smoke had cleared

Ministry of Health failed to heed the warning. Only repeated medical resistance forced the department to modify its plan, and it took a pragmatic Labour minister, Aneurin Bevan, to remove the last vestige of local authority control in 1945.

Thereafter other objections arose and Bevan had to make further concessions before the NHS began in July, 1948. But once in it the doctors learnt to like the NHS just as they had come to support the panel system. By 1989, in the face of a radical reorganisation proposed by a Conservative government, they had become the ardent defenders of a nationalised structure that was foisted on them by a socialist minister in 1948. Consultants, like general practitioners before them, found refuge in the doctrine of central control. Just as panel practitioners favoured national contracts to free themselves from the approved society majority on insurance committees, so consultants welcomed regional appointments and uniform terms of service to avoid interference from local authorities. And now not only had the approved societies gone but so had the spectre of municipal control.

Nor was that all: as with club practice and the panel system before it (with minor exceptions) only registered practitioners were admitted to the new service, thereby extending the profession's protection against unqualified practice to the nation as a whole. Clinical freedom was enlarged as well: doctors no longer had to worry about a patient's ability to pay before deciding what treatment to give. The profession enjoyed greater freedom than it had experienced at any time since club practice began in the $1820 \mathrm{~s}$.

In the process the public benefited, too, in receiving a service that, in the words of the Archbishop of York in 1946, promised to "bring a health, happiness and security to millions in a way which no previous Acts of Parliament ever have done." Though no organised group spoke for patients during the debates of the 1940 s, it was doubtful whether the doctors would have succeeded if their interests had not coincided with those of consumers. The BMF reported Dr Cox's address to a conference for local medical and panel committees nearly sixty years ago:

$\mathrm{He}$ [Dr Cox] had had one principle underlying all his work namely, that the Association would never be successful unless at the back of it all was a sincere desire to further the interests of the public. If the Association could not convince the public that in addition to looking after the interests of the profession, as it was bound to do, it had a great desire to make the medical service better, then it would never get the results it ought to achieve. He begged them to hold fast to the principle that they were out first and foremost for the interests of their patients. Capitation fees were important, but they were not the main thing." "I

Today medical freedom is again under threat, this time from a government that is determined to make doctors accountable for the work they do. Freedom for the profession, it feels, has gone too far, producing what Sir John Brotherston (before he became chief medical officer of the Scottish Department of Health) 
once called a system of "syndicalistic anarchy" in the administration of the health service. Somehow, the government believes, a balance must be struck between organisation and freedom.

Is this demand reasonable? The final answer no doubt rests with the public. If patient care suffers in the process then the nation may decide that the restraints imposed are not worth the savings they produce. Today, as in 1911 and 1948, it is the public interest that will predominate.

Material in this paper is taken mainly from the following:

Honigsbaum F. Health, happiness and security. The creation of the National Health Service. London: Routledge, 1989
Honigsbaum F. The division in British medicine. A history of the separation of general practice from hospital care, 1911-1968. London: Kogan Page, 1979.

Honigsbaum F. The struggle for the Ministry of Health, 1914-1919. London: G Bell, 1970. (Occasional papers on social administration No 37.)

Other sources are numbered in the text:

1 Webb S, Webb B. The state and the doctor. London: Longman, 1910.

2 Richardson R. Death, dissection and the destitute. London: Routledge, 1988.

3 Frazer WM. A history of English public health 1834-1939. London: Baillière, Tindall and Cox, 1950.

4 Wilson N. Municipal health services. London: Allen and Unwin, 1946.

5 Levitt R. The reorganised health service. London: Croom Helm, 1976.

6 Cronin AJ. The citadel. London: Gollancz, 1937.

7 Anonymous. $\mathrm{Br}$ Med $\mathcal{F} 1905 ; \mathrm{ii}($ suppl):1-96. Report on contract practice.

8 Anonymous. "How it strikes us." Medical World 1922 July 28:507.

9 Anonymous. Insurance: the court's award. Br Med f 1924;i:205-6.

10 British Medical Association. Report of the committee on fractures. Br Med $\mathcal{F}$ 1935; (suppl):53-62.

11 Anonymous. Annual panel conference. Br Med $\mathcal{F}$ 1931;ii(suppl):256

\section{Playing at Doctors (1863)}

Frederick Daniel Hardy (1826-1911; British)

Frederick Daniel Hardy has connections with the first artist in the series, Thomas Webster (p 687). Hardy studied with him, subsequently became a member of the Cranbrook Colony, and, like his master, went on to specialise in scenes of children at play. These pictures sold well and provided him with a comfortable living, an ambience reflected in this picture, which shows privileged children in a cosy middle class setting. Seemingly a straightforward representation of a children's game, does "Playing at Doctors" have a deeper meaning? The clue to this may lie in the two women in the doorway; one is middle aged, the other elderly. Possibly, then,

Hardy is showing us three stages of life-and the game in progress refers to the frailty of old age.

Hardy's strength lies in his accurate observation and attention to detail, particularly of contemporary

Victorian interior decoration; his pictures have even been used by specialists as an authentic source of information.

\section{CLASSIC OF THE DECADE}

1865: Claude Bernard's Introduction $\grave{a}$ l'Étude de la Médecine Expérimentale. Paris: J B Baillière.

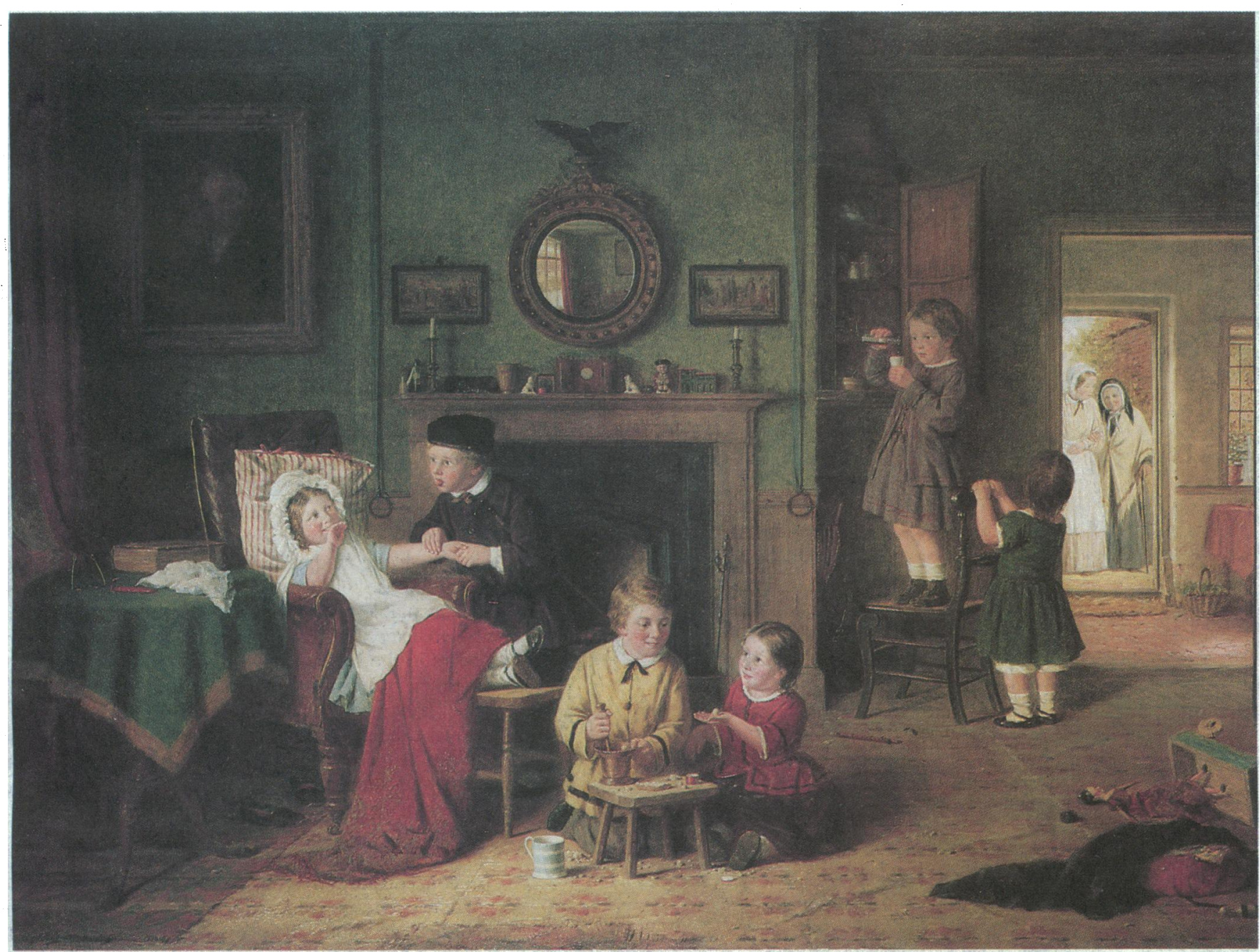

